\title{
Is foreign trade important for regional growth? Empirical evidence from Portugal.
}

\begin{abstract}
The aim of this study is to investigate whether openness, exports shares or trade balances affect regional growth in Portugal. Human capital is also considered as a conditional factor to growth, expressed by the rate of success in high school education. Thus, we analyse whether the combination of international trade and human capital is relevant to explain regional growth in Portugal and how it affects the convergence process between regions. In the empirical analysis, interaction terms are introduced to explore the existence of different performances between regions of the Littoral and the Interior. As an alternative to the traditional approach that considers the population growth rate, we include the share of sectoral employment aiming to capture labour specialisation in the main sectors of economic activity and measure its impact on regional growth.

The empirical analysis estimates the conditional convergence model of the Barro's type, applied to the Portuguese NUTS3 regions for the period 1996-2005. The GMM estimation approach applied to regional panel data reveals that factors associated with external trade, human capital and sectoral labour share (especially of the industrial sector) are relevant to explain regional growth and convergence in Portugal.
\end{abstract}

Keywords: conditional convergence, human capital, external trade, employment share, GMM regressions, panel data

JEL codes: E12, F43, O11 


\section{Introduction}

Different approaches have been used to test the convergence hypothesis, the most common being the conditional convergence developed by Barro and Sala-i-Martin [1]. According to this approach, growth is conditioned by structural factors such as human capital accumulation, technical progress, innovation, among others, with increasing returns to scale characteristics. Differences on these structural factors characterise properly the steady-states of the economies and explain the capability of the backward economies to grow faster than the advanced ones.

Several studies have been carried out at the European level to analyse the convergence phenomenon among regions, using different approaches, samples and time periods. ${ }^{1} \mathrm{~A}$ great number of studies also deal with regional convergence within a given country. Some examples are those by De la Fuente [6], Vittorio [7], and Michelis et al. [8], for the Spanish, Italian and Greek regions, respectively. In the particular case of Portugal, Crespo and Fontoura $[9,10]$ analysed the convergence process at the municipal level. Antunes and Soukiazis [11] showed that Structural Funds received from the EU had contributed to a higher convergence of the Portuguese NUTS3 regions and Soukiazis and Proença [12] provided empirical evidence showing that tourism was a factor of regional convergence.

In all the above-mentioned studies foreign trade was not considered as a factor of convergence. It is argued that when a region faces an external deficit, capital flows from the central government can solve this problem. ${ }^{2}$ We do not share this view for several reasons: (i) regional external deficits reflect lack of economic competitiveness which can constrain local growth and increase unemployment [17]; (ii) capital transfers from the central government to the deficit regions are not sustainable in the long-term and can create budget deficits that affect the whole economy; (iii) capital transfers from the central government to less competitive regions can be inefficient in terms of the optimal reallocation of resources; (iv) the reallocation of resources to less competitive regions with the aim to finance external regional deficits can be made in detriment of other

\footnotetext{
${ }^{1}$ See for instance, Cappelen et al. [2], Battisti and Di Vaio [3], Meliciani and Peracchi [4] and Herz and Vogel [5].

${ }^{2}$ Ramos [13] in line with other authors like Bayoumi and Rose [14], Helliwell and McKitrick [15] and Decressin and Disyatat [16], argues that regions can run external imbalances in a greater scale than countries and since they avoid sustainability constrains they may even benefit from those imbalances.
} 
regions increasing, therefore, regional inequality. In our opinion, regional trade competitiveness is important for local growth as it is for the whole economy, and capital flows are not a sustainable solution in the long-term. Structural solutions are needed to turn regions more competitive by allocating resources to sectors with increasing returns to scale characteristics and encouraging the production of goods with high incomeelasticity of demand in international markets.

The aim of the present study is to test the convergence hypothesis of per capita income among the Portuguese NUTS3 regions for the period 1996-2005, using different conditional factors. The main contributions of the paper are: (i) foreign trade indicators are introduced into the growth model to measure their impact on regional growth and convergence; (ii) sectoral employment share is considered in the growth equation as an alternative to population growth which is usually used in growth models of the Barro type; (iii) the dichotomy between the Littoral (coastal) and the Interior (in-land) zones is shown to be relevant in the process of convergence in Portugal; (iv) technology diffusion effects are detected by adding an interaction term between foreign trade and human capital into the growth model. These issues have not been studied before at a regional level for the same country and mostly for Portugal.

The study is organised as follows: in section 2 the growth and convergence issues are discussed and the importance of trade for growth is explained. In section 3 the convergence model is adapted to include trade as a conditioning factor of growth. Section 4 provides statistical information that allows analysing regional asymmetries with respect to per capita income, foreign trade, educational standards and employment structure. In section 5 the conditional convergence model is estimated and the results are discussed. The last section summarises the most relevant outcomes from the study.

\section{The importance of trade on growth and convergence}

The origin of the studies on economic growth and convergence is based on the Solow's [18] neoclassical growth theory. According to this theory, factors of production move freely, face diminishing returns and decreasing marginal productivity. Technological progress is exogenous and freely available to everyone. Under these circumstances, convergence in per capita income will occur, indicating that poorer economies grow faster than the richer ones. Empirically, this tendency is confirmed by the negative 
correlation between the growth of per capita income and its initial level (absolute convergence). In the long-term, all economies will grow at similar rates and converge to the same steady-state. Trade is not considered as an impediment to growth since flexible relative prices solve trade imbalances and bring the economy back to equilibrium.

Romer's [19] work pointed out the failure of the neoclassical convergence hypothesis, when confronted with empirical evidence. Growth models with increasing returns to scale (coming mainly from human capital and technological progress) became an alternative to the neoclassical approach. Baumol [20], Barro and Sala-i-Martin [21] and Mankiw et al. [22] assessed the existence of conditional convergence when differences on structural factors (human capital, technological progress and innovation, among others) were taken into account. Most of the theoretical growth models are based on aggregate production functions with physical capital, human capital and technology as the relevant explanatory factors of income growth [23, 24, 25]. Different economies converge to different steady-states, characterised by dissimilar economic structures, thus reflecting differences in production functions.

Empirical studies testing the hypothesis of conditional convergence have not sufficiently explored the possibility that trade can be a conditioning factor of growth. ${ }^{3}$ The absence of trade considerations is more evident in studies of regional convergence within the same country.

The influence of trade on growth can be explained through several channels: trade is responsible for technological and knowledge transfers among trading partners; trade is essential for exploiting economies of scale due to market size; trade allows for a better reallocation of resources towards the more productive sectors; trade enhances higher product specialisation according to the comparative advantages principle [27, 28, 29]. In fact, international trade is considered to be a privileged way of transmission of R\&D spillovers, namely through the acquisition of intermediate products and capital equipment containing foreign technology and innovation activities [30]. Therefore, trade affects convergence not only through the price mechanism [25] but also because the trade of goods and services, incorporating sophisticated technology and new ideas, accelerates technological diffusion among economies [31].

\footnotetext{
${ }^{3}$ An exception is the study by Antunes and Soukiazis [26], where the balance-of-payments constraint hypothesis and the degree of openness are considered as conditioning factors to explain the convergence process between the early EU countries.
} 
Trade openness is by itself an incentive for economies to get involved in innovative activities, thus favouring growth in the long-term. In this context, a link between trade openness, human capital and technological changes can be established. The stock of human capital is more likely to embrace $R \& D$ activities than the non-specialised workforce. The higher innovation rate enabled by R\&D activities is further stimulated by the existence of an international market where new products and services can be traded and technological diffusion promoted.

All the above arguments justify the inclusion of trade measures in the growth equations when estimated empirically. The omission of this factor can bias the results.

\section{The convergence model with trade}

The convergence equation more often estimated in the empirical literature is of the Barro's type, assuming that human capital is partly endogenous with increasing returns properties in the long-term that compensate the diminishing returns of physical capital. The model has been adjusted by Mankiw et al. [22] to include human capital and by Islam [23] to be used with panel data, controlling for differences in the production function among different economies. According to these authors, the convergence equation is given by the following relation: ${ }^{4}$

$$
\begin{aligned}
& \ln y_{i}\left(t_{2}\right)-\ln y_{i}\left(t_{1}\right)= \\
& =\theta \ln A_{0}+g t-\theta \ln y_{i}\left(t_{1}\right)-\theta \frac{a}{1-a} \ln \left(n_{i, t}+g+\delta\right)+\theta \frac{a}{1-a} \ln \left(s_{i, t}\right)+\theta \frac{\beta}{1-\alpha} \ln \left(h_{i, t}\right)+\theta \frac{\gamma}{1-a} \ln \left(m_{i, t}\right)+v_{i, t}
\end{aligned}
$$

In this expression, $y$ is per capita income, $n$ the annual growth rate of population, $g$ the growth of technology, $\delta$ the depreciation rate, $s$ the savings (investment) rate, $h$ human capital and $m$ is trade. On the other hand, $\alpha, \beta$ and $\gamma$ are growth elasticities with respect to physical capital, human capital and trade, respectively. Finally, $\theta=\left(1-e^{-\lambda T}\right)$ with $\lambda$ the speed of convergence, $g t$ is a constant (technological progress is assumed to be the same for all economies) and $A_{0}$ reflects not only the technological level but also resource endowments, the legal system and institutions, among others, and thus it may differ across economies. The term $\theta \ln A_{0}$ is the time-invariant individual effect reflecting the economy's specific effects and $v_{i t}$ is the error term that varies across countries and time periods. Estimating equation (1) by panel data techniques is the way to control for the individual effects.

\footnotetext{
${ }^{4}$ The convergence equation has been adapted to include trade.
} 
In our analysis, several alternative proxies for external trade are considered. We distinguish two kinds of external trade flows according to the trading partners involved: trade with the EU countries, labelled intra-trade and trade outside the EU area, labelled extra-trade. Given this distinction, we consider the degree of openness (ratio of external trade to GDP) and the trade balance as percentage of GDP, in both situations - intra and extra-EU. Additionally, the intra-, extra-, and total-exports ratio (as percentages of GDP) are used as conditioning factors of regional growth in Portugal. From the theoretical description of the model, we expect external trade variables to have a positive impact on regional growth.

Interaction terms between the external trade variables and the Littoral area (dummy variable) are also included, to analyse the existence of different impacts on growth depending on the location of the regions (Littoral versus Interior). Lastly, an interaction term between foreign trade and human capital is considered, to investigate the presence of technological diffusion occurring through trade openness.

The main task of the study is to verify whether human capital, external trade and sectoral labour share are relevant factors to suitably explain differences in steady-states among regions with diversified structures.

\section{Regional disparities in Portugal}

\subsection{Differences in regional per capita income}

Portugal is divided in 30 NUTS3 regions and the geographical distribution of the regions can be seen in Figure 1 in the Appendix. The option for a more disaggregated territorial unit like the NUTS3 enables us to compute regional per capita GDP, the indicator most commonly used to compare standards of living or levels of development between regions. Table 1 displays the regional per capita income levels (at constant prices), ${ }^{5}$ according to the NUTS3 division for the period 1996 to 2005 , as well as the relative positions both at the initial and final years.

\section{[Insert Table 1 here]}

\footnotetext{
${ }^{5}$ Monetary values have been deflated by the CPI of NUTS2 and the data was taken from the National Institute of Statistics (March 2010), after a formal request by the authors.
} 
Ranking the regions in descending order according to per capita income, we observe that in 1996 the six first places belong to Grande Lisboa (19.64), Alentejo Litoral (16.40), Grande Porto (14.44), Algarve (13.32), Pinhal Litoral (13.19) and Baixo Mondego (12.40). On the other extreme with the lowest per capita income appear AltoTrás-os-Montes (8.16), Douro (8.00), Beira Interior Norte (7.77), Pinhal Interior Norte (7.17), Tâmega (6.70) and Serra da Estrela (6.31).

After a decade, in 2005, the situation is the following: Grande Lisboa (25.47), Alentejo Litoral (21.98), Madeira (18.96), Algarve (16.40), Baixo Mondego (15.71) and Grande Porto (15.27) are the regions with the highest per capita income, whereas the last places belong to Cova da Beira (10.23), Douro (10.20), Minho-Lima (9.47), Serra da Estrela (9.20), Pinhal Interior Norte (9.01) and Tâmega (8.47).

Dividing the NUTS3 regions into two major groups - Littoral (coastal regions) and Interior (inland regions) ${ }^{6}$ - it is possible to verify that the first group contains the more developed regions, whereas the latter includes the less developed areas, either in 1996 or in 2005 (the exception is Minho-Lima, a Littoral region that is part of the bottomgroup of per capita income in 2005). Therefore the dichotomy in Portugal is not between North and South (as usually happens in other countries) but between West (the coastal zone) and East (the inland area).

Thus, comparing the initial and final years of the analysis, four of the regions in the last six positions of the table remain the same, although only Douro maintains its relative position $\left(26^{\text {th }}\right)$. Additionally, only Pinhal Litoral abandons the top-six group from 1996 to 2005. The most pronounced changes are those from the islands of Madeira and Azores, both climbing 10 positions in the ranking within the period. These remarkable changes are probably due to financial support received from the central government, without significant paybacks. Another key factor is tourism, a predominant dynamic sector promoting growth on these islands. Regarding the drops, the most evident case is that of Entre Douro e Vouga, falling from the $10^{\text {th }}$ to the $17^{\text {th }}$ position. In global terms, between 1996 and 2005 four regions kept their position in terms of per capita income (Grande Lisboa, Alentejo Litoral, Algarve and Douro), 10 improved and 16 deteriorated their relative position.

\footnotetext{
${ }^{6}$ The Portuguese NUTS3 regions were divided (according to their geographical location) in two groups: the Littoral area with 16 coastal regions and the Interior area with 14 inland regions. For this division, see Figure 1 in the Appendix.
} 
Table 2 offers an alternative perspective of regional disparities, where regional per capita income is compared to the weighted national average for the period 1996 to $2005 .^{7}$ We can observe that in the first year, five regions present a result higher than $100 \%$. Grande Lisboa is on the top, having a per capita income about 56\% higher than the average. In 2005, the number of regions with a living standard higher than the average ascended to seven. The most relevant increases occurred in Madeira, Alentejo Litoral, Grande Lisboa and Serra da Estrela.

\section{[Insert Table 2 here]}

In general terms, the figures for the Littoral and the Interior zones do not vary much during the period of analysis. However, it is worth mentioning that the performance of the Littoral is always about $10 \%$ higher than the average, whereas the Interior is around $30 \%$ below the average, despite the tendency for improvement in the last years of the analysis. Having this in mind, the distinction between these two areas is important to understand regional disparities in Portugal.

\subsection{Income dispersion}

One of the most commonly used concepts to verify if differences in per capita income narrow or widen over time is that of $\sigma$-convergence. The coefficient of variation is used to measure $\sigma$-convergence given by the standard deviation over the sample mean. When this coefficient is declining over time the dispersion of income decreases among regions and this is evidence of $\sigma$-convergence. Alternatively, an increase of this indicator shows that asymmetries in income amplified over time among the regions of the sample.

Table 3 provides the figures of the coefficient of variation for the total sample (30 regions) and the regions of the Littoral (16) and Interior (14), and Figure 2 plots these results. It can be seen that for the whole sample asymmetries in per capita income increased moderately over time and the same tendency is observed in the Littoral area. Regarding the Interior zone the tendency is the opposite, showing a decline in the dispersion of income over time. This means that asymmetries are higher between the

\footnotetext{
${ }^{7}$ The weighted national average is computed as: $\overline{G D P p c}_{\text {Portugal }, t}=\left(\sum_{i=1}^{30} G D P p c_{i, t} *\right.$ pop $\left._{i, t}\right) / \sum_{i=1}^{30}$ pop $_{i, t}$, with $\mathrm{i}=1, \ldots, 30$ and $\mathrm{t}=1996, \ldots, 2005$.
} 
more developed regions of the Littoral and that the less developed regions of the Interior become more homogeneous. In fact, there is a different performance in per capita income between these two areas and this has to be taken into account in the estimation approach. The conclusions remain roughly the same if we exclude the islands of Azores and Madeira from this analysis, the regions with the most expressive improvements in per capita income performance.

\section{[Insert Table 3 and Figure 2 here]}

\subsection{Foreign trade indicators}

The evolution of foreign trade indicators is presented in Table 4, for the whole sample, the Littoral and the Interior areas and for the first and last years of the analysis. The first variable, Open-Extra, refers to the degree of regional openness, considering both the exports and imports of goods with the non-EU countries. The second variable, Open-Intra, refers to the degree of regional openness with respect to the EU countries. The third variable, Exports-Intra/GDP, corresponds to the exports ratio with the EU countries and the last variable, Total-Exports/GDP, considers the ratio of total regional exports to the EU and non-EU countries.

\section{[Insert Table 4 here]}

From Table 4 it can be observed that the regional trade relations are much higher with the EU countries, as expected; regions of the Littoral area (the most developed) are on average much more open than the regions of the Interior area (the less developed), both with respect to the EU and the non-EU countries. The same situation is verified with respect to Exports-Intra/GDP and Total-Exports/GDP ratios. The Littoral area is shown to be more dynamic in the exports sector both with respect to the EU countries and the rest of the world. Combining this finding with the fact that regions from the Littoral are richer than those from the Interior, a strong relation can be established between regional development and foreign trade. This relation is shown more formally in the empirical analysis of the next section.

\subsection{Educational standards}

Table 5 illustrates regional education standards by using the rate of transition/conclusion in high school between 1996 and 2005 at the NUTS3 level. 
Generally, it is shown that educational standards are improving over time but in a modest way. The fall of educational standards in some regions can be explained by specific socioeconomic characteristics of the population and qualitative factors of the educational system. Educational standards remain quite stable over time and do not vary much across regions, especially if we consider the Littoral/Interior division. Since differences in educational levels are not very significant among regions, the distinction Littoral/Interior is not important in the estimation approach with respect to this variable.

\section{[Insert Table 5 here]}

\subsection{Employment share by sector of activity}

The share of employment in each of the three main sectors of economic activity is displayed on Table 6, for each region in the years 1996 and 2005, as well as the corresponding absolute variation. The following general remarks can be made: (i) we assist to a relative employment reduction in the primary sector although in some regions the employment in this sector is still high (Pinhal Interior Sul - 50.20\%, Alto Trás-osMontes $-47.41 \%$, Beira Interior Norte $-43.56 \%$ and Douro - $43.22 \%$ ); (ii) in the less developed Interior area, employment in the primary sector is about three times higher than in the Littoral in 2005; (iii) employment in the secondary sector is also diminishing on average, with the Littoral area showing a higher share than the Interior. The declining share of employment in the secondary sector can be associated with a deindustrialisation process; (iv) there is a general increase on employment in the services sector, with the Littoral displaying a higher share. Although this is a characteristic of the modern economies, it can be taken as a sign of concern. With the exception of some dynamic activities (telecommunications, banking system and tourism, among others) this sector produces mostly non-tradable goods with low value added and it is highly dependent on imports. ${ }^{8}$ From the point of view of regional growth, the concentration of the economic activity on services and the relative decline of the secondary sector concerning industrial and manufacturing activities can be disadvantageous. The positive externalities and complementary effects spreading from the industrial sector to other sectors of economic activity can be lost enhancing higher imports flows.

\footnotetext{
${ }^{8} \mathrm{~A}$ more disaggregated sectoral analysis is needed to derive more consistent conclusions on this issue. However, data on sub-sectors are not sufficiently disaggregated at the NUTS3 level to provide us with a more detailed analysis by sector.
} 


\section{[Insert Table 6 here]}

\section{Empirical results}

\subsection{The model and the variables}

In the empirical analysis we consider the growth model as was adapted by Islam [23] and Caselli et al. [32] to panel data. The general specification of the growth equation is of the following form: ${ }^{9}$

$$
\begin{aligned}
& \Delta \ln G D P p c_{i, t}=b \ln G D P p c_{i, t-1}+c_{1} \ln \left(n_{i, t}+g+\delta\right)+c_{2} \ln \left(S c h o o l_{i, t-1}+c_{3} \ln (F T)_{i, t}+v_{i, t}\right. \\
& v_{i, t}=\alpha_{i}+u_{i, t}
\end{aligned}
$$

In this equation, $\alpha_{i}$ stands for the specific individual regional effects, such as differences in the initial level of efficiency or specific measurement errors of the economies [33] and $u_{i, t}$ is the idiosyncratic error term. The index $i$ refers to region and $t$ to year. This equation relates the growth of per capita income of each region to its initial level and a set of conditioning factors, such as the population growth rate ${ }^{10}$ (or alternatively the sectoral employment share), schooling standards, and foreign trade measures. ${ }^{11}$ Scholar standards are given by the rate of transition/conclusion in high school (School) as a proxy for human capital. Several alternative indicators of foreign trade (FT) are used, namely: the trade balance (as percentage of GDP) related to the trade of goods with the EU countries (TB-Intra); the degree of openness with the countries outside the EU (Open-Extra); the exports ratio with the EU countries (Exports-Intra/GDP); the total exports ratio with the rest of the world ((Total-Exports)/GDP); and finally, the growth rate of the ratio of exports to non-EU countries over GDP ( $g$ (Exports-Extra)/GDP). ${ }^{12}$

It is expected a negative correlation between the growth of per capita income and the initial level implying that poorer regions grow faster than the richer ones as the convergence hypothesis claims. On the other hand, educational standards and external trade are expected to positively affect regional growth in Portugal. Population growth

\footnotetext{
${ }^{9}$ This is a simplified form of Equation (1).

${ }^{10}$ This variable includes the sum $(g+\delta)=0.05$, of the rate of technological progress and the capital depreciation rate, equal to all years and across regions.

${ }^{11}$ The savings (investment) rate is not included in the convergence equation, since there is no available data for this variable at the NUTS3 level in Portugal.

${ }^{12}$ Variables are expressed in logs except the trade balance, since it displays some negative values.
} 
may influence negatively regional growth since the available productive resources must be distributed more thinly among the working population. However, it can also have a positive effect on growth through the increase in effective demand. The final impact on regional growth will depend on which of these two effects prevails. As an alternative to the population growth rate, we use the share of employment in the secondary sector $(\mathrm{Sec})$ as a proxy for sectoral labour allocation. ${ }^{13}$ An increase of the share of the secondary sector either in terms of employment or of production is expected to lead to a higher regional growth, given the interdependence and the complementarities between many of the industrial activities and those from other sectors. On the other hand, the existence of positive externalities stemming from the innovation processes of the secondary sector is equally important, benefiting other sectors as well.

\subsection{The estimation method}

The specification of a dynamic panel data model is the most adequate approach to analyse regional growth, bearing in mind the existence of specific individual effects. GMM (Generalised Method of Moments) is the estimation method most commonly used in dynamic models with panel data and a lagged dependent variable. This method uses a set of instrumental variables to solve the endogeneity problem of the regressors. There are two types of GMM estimators (difference and system) and they can be both alternatively considered in their one-step and two-step versions. ${ }^{14}$ The set of instruments of the difference-GMM estimator includes all available lags of the levels of the endogenous variables and the strictly exogenous regressors [34, 35]. The system-GMM estimator includes not only the previous instruments, but also the lagged differences of the variables $[36,37]$. We present the most reasonable results, those that behave favourably in terms of the diagnostic tests of overidentification (Hansen-J test) and absence of $2^{\text {nd }}$ order autocorrelation in first differences (AR2 test). The number of instruments used in each regression is indicated and it was necessary to reduce the lag order and use the collapse option, to decrease the width of the instruments matrix. In small samples this is a very useful option, since it prevents the number of instruments

\footnotetext{
${ }^{13}$ The employment share in the secondary sector proved to be statistically more relevant in the estimations ran than the employment shares in the other two sectors. In fact, the employment share in the primary sector had a negative impact on regional growth and that of services, a positive impact with no statistical significance.

${ }^{14}$ While in the first case the errors are iid, the two-step estimator accounts for the existence of heteroscedasticity [31].
} 
from exceeding the number of units (regions) and the consequent bias that arises from this problem [38]. In the regressions $\operatorname{ran}^{15}$ all the explanatory variables are assumed endogenous, except the interaction terms.

\subsection{Analysis of the regression results}

Equation 2 is estimated by the GMM method and Table 7 displays the obtained results. In these estimations, a balanced panel is used for the sample of 28 NUTS3 regions of the Portuguese Continent ${ }^{16}$ for the period 1996 to 2005 . The outcomes are quite promising. The first aspect to notice is that conditional convergence is found in all cases, ${ }^{17}$ confirmed by the negative sign on the initial income (lagged one period) and statistical significance at the conventional probability levels.

\section{[Insert Table 7 here]}

The second important result is that educational standards (proxy for human capital) present the expected positive and statistically significant impact on regional growth, revealing that education is a factor of regional convergence. ${ }^{18}$ This is in line with the endogenous growth theory claiming that human capital is a factor of production with increasing returns to scale properties and substantial positive externalities in the longterm, thus contributing to higher growth.

The third relevant conclusion is that population growth has not a significant impact on regional growth although its effect is found to be positive (columns (1) and (2) of Table 7). This insignificance can be due to the low growth of population in Portugal or even stagnancy in recent years. Alternatively, when population growth is substituted by the employment share in the secondary sector, its effect on regional growth is positive and statistically significant in all cases (columns (3) to (7) of Table 7). It is worth mentioning that is was not possible to find statistical significance when this variable was replaced by the share of employment in the tertiary sector. When the share of

\footnotetext{
${ }^{15}$ The regressions were run by Stata.

${ }^{16}$ In order to use balanced panel data it was necessary to exclude the regions of Azores and Madeira, because data are not available for the whole period considered. On the other hand, these regions benefit from some special conditions and might bias the global results if included.

${ }^{17}$ The evidence of conditional convergence ( $\beta$-convergence) does not contradict the lack of $\sigma$ convergence found in the analysis of the income dispersion. As Barro and Sala-i-Martin [39] argue, $\beta$ convergence is a necessary but not a sufficient condition for $\sigma$-convergence to occur.

${ }^{18}$ The human capital variable appears in these regressions lagged one period. This is in line with the perspective that the effect of human capital on growth is not immediate.
} 
employment in the primary sector was used, it displayed the expected negative sign, but the remaining results were not satisfactory (namely, human capital lost statistical significance).

The fourth significant result comes from the foreign trade variables. In columns (1) and (2) it is shown that the degree of openness with the non-EU countries and the exports ratio with the EU countries have a positive and significant impact on regional growth. However this positive effect is only statistically confirmed when these variables are multiplied by the Littoral dummy. This result reinforces the idea that more open and export-orientated regions grow faster and contribute to regional growth as a whole in Portugal. This reveals the existence of some kind of positive externalities from the more competitive regions that benefit the whole economy. In fact, as we have confirmed in the previous section, the regions of the Littoral are much more open and much more dynamic in the exports sector in comparison to the inland regions of the Interior. The same conclusion is obtained from columns (4) and (5) of Table 7, where the employment share in the secondary sector is used instead of the population growth.

In column (3), trade balance with the EU countries (as a percentage of GDP) is used as a measure of foreign trade. Its positive and statistically significant effect (at the 10\% level) on regional growth implies that the higher the trade surplus the higher the growth implying on the other hand that higher deficits are harmful to growth. Therefore, higher competitiveness is an important factor for regional growth and convergence. Column (6) shows that total exports ratio with the EU and non-EU countries of the Littoral area contribute positively to global regional growth. This evidence is in accord with the export-led growth hypothesis claiming that exports are the engine of growth explained by the foreign trade multiplier.

Finally, in column (7), human capital is combined with the growth of the ratio of nonEU exports to GDP. ${ }^{19}$ The interaction term is lagged one period and aims to express the technological diffusion hypothesis that takes place through external trade. It can be seen that the impact of the growth of exports on regional growth is positive, as long as the rate of transition/conclusion in high school is higher than $60 \%{ }^{20}$ (this variable varies

\footnotetext{
19 The individual impact of human capital is not statistically significant but its removal from the regression would not change the results to a great extent.

20 The cut-off point is obtained from:
} 
between 55.5 and 73.4\%, as it is shown in Table 5). Therefore the positive impact of regional openness on growth requires higher levels of educational standards, necessary to assimilate the advanced technologies transferred through international trade. For a region to achieve higher growth rates it is necessary to be competitive in international markets and competitiveness is linked to human capital qualifications. The latter is important for adopting and understanding new technologies and developing new products able to compete in international markets. Lastly, the convergence obtained from this estimation is the highest, suggesting that exports combined with human capital qualifications are the engine of growth helping regions to grow faster and to converge. Still regarding column (7), the impact of human capital on growth is positive, as long as the growth of the ratio of (extra-EU) exports is positive. Thus, regions that are not able to achieve positive growth rates on exports face difficulties to obtain the desired effects of human capital on growth. This analysis gives evidence of the joint effects between human capital and foreign trade on regional growth; hence, one effect cannot be dissociated from the other.

\section{Final conclusions}

The basic idea of this study was to show that foreign trade is important for regional growth in Portugal as it is important for the whole country, not sharing the argument that capital flows from the central government solve the problem of regional trade imbalances. For this reason the empirical analysis estimates growth equations that take into account foreign trade measures (along with human capital and sectoral employment shares) and tests their statistical relevance on regional growth and convergence.

The descriptive analysis shows that the Portuguese dichotomy between Littoral (16 coastal regions) and Interior (14 inland regions) is important for understanding regional asymmetries. Regions of the Littoral have generally higher standards of living, are more open to trade and more competitive in international markets. Differences on educational standards are not substantial between the two areas. The descriptive analysis also illustrates a severe structural problem in Portugal, associated with the deindustrialisation tendency that can partly explain the low growth rates of Portugal over the last years.

\footnotetext{
$\frac{\partial g G D P p c}{\partial g(\text { Exports }- \text { Extra } / G D P)}=0 \Leftrightarrow-0.0217+0.0053 \ln ($ School $)=0 \Leftrightarrow \ln ($ School $)=0.0217 / 0.0053$

$\Rightarrow$ School $=\exp (0.0217 / 0.0053) \cong 60$
} 
The employment shares in the primary and secondary sectors have fallen between 1996 and 2005 followed by a relative increase in the services sector. The concentration of the economic activity on the latter can be disadvantageous since several activities are associated with the non-tradable sector, produce low value added products and are highly dependent on imports.

The empirical analysis based on GMM regressions of the conditional convergence model provides interesting insights for the sample of the NUTS3 regions over the period 1996-2005. Conditional convergence is found and population growth plays an insignificant role in regional growth. The employment share in the secondary sector is shown to be more important for growth relatively to employment shares in the two other sectors, affecting regional growth positively. Another important finding is the confirmation that educational standards are important for regional growth and this is in line with the endogenous growth theory asserting that human capital is the engine of growth.

The focus of our empirical analysis is on the importance of foreign trade on regional growth and convergence. In fact our results are robust with respect to this factor. It is shown that different measures of foreign trade, such as the degree of openness, the share of intra- and total-exports to GDP, the trade balance with the EU and the growth rate of the extra-EU exports ratio significantly influence regional growth and contribute to the convergence process. However, trade with the EU countries is more significant than with non-EU members, as expected, since Portugal is a member of this group. The fact that foreign trade measures gain significance only when they are combined with the Littoral dummy (the more competitive and more open area), reinforces the view that external trade is essential for higher regional growth. It also indicates some externality effects from the Littoral area that positively influence global regional growth and convergence. Finally, the significance of the interaction terms between human capital and foreign trade can be taken as evidence of the technology diffusion principle. More qualified human capital is thus required to assimilate modern technologies and to turn the economies more competitive and able to compete successfully in international markets. 


\section{Appendix}

Figure 1. 30 Portuguese NUTS3 regions

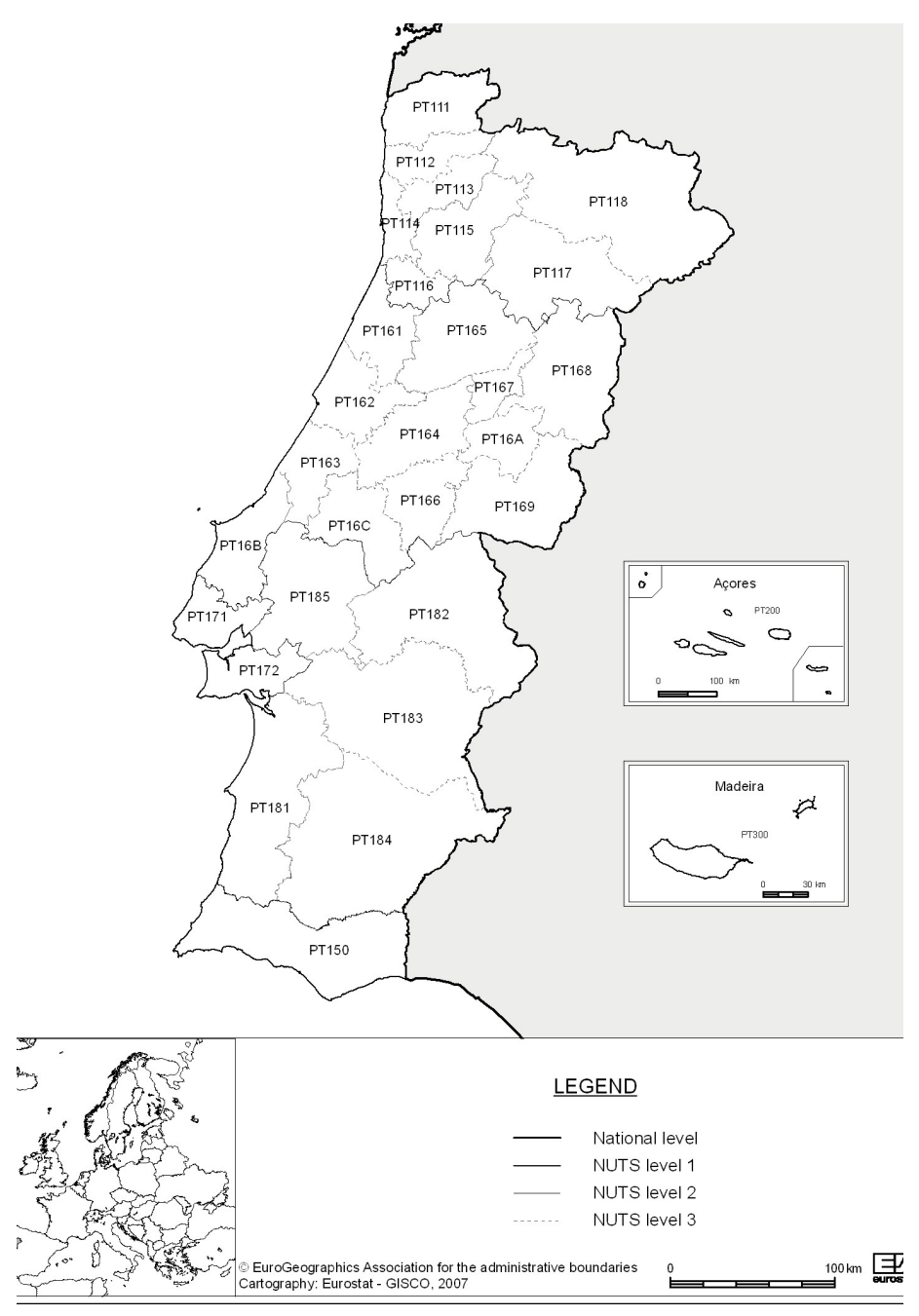

$\begin{array}{lc}\text { Code } & \text { NUTS3 level } \\ \text { PT111 } & \text { Minho-Lima (L) } \\ \text { PT112 } & \text { Cávado (L) } \\ \text { PT113 } & \text { Ave (L) } \\ \text { PT114 } & \text { Grande Porto (L) } \\ \text { PT115 } & \text { Tâmega (I) } \\ \text { PT116 } & \text { Entre Douro e Vouga (L) } \\ \text { PT117 } & \text { Douro (I) } \\ \text { PT118 } & \text { Alto Trás-os-Montes (I) } \\ \text { PT150 } & \text { Algarve (L) } \\ \text { PT161 } & \text { Baixo Vouga (L) } \\ \text { PT162 } & \text { Baixo Mondego (L) } \\ \text { PT163 } & \text { Pinhal Litoral (L) } \\ \text { PT164 } & \text { Pinhal Interior Norte (I) } \\ \text { PT165 } & \text { Dão-Lafões (I) } \\ \text { PT166 } & \text { Pinhal Interior Sul (I) } \\ \text { PT167 } & \text { Serra da Estrela (I) } \\ \text { PT168 } & \text { Beira Interior Norte (I) } \\ \text { PT169 } & \text { Beira Interior Sul (I) } \\ \text { PT16A } & \text { Cova da Beira (I) } \\ \text { PT16B } & \text { Oeste (L) } \\ \text { PT16C } & \text { Médio Tejo (I) } \\ \text { PT171 } & \text { Grande Lisboa (L) } \\ \text { PT172 } & \text { Península de Setúbal (L) } \\ \text { PT181 } & \text { Alentejo Litoral (L) } \\ \text { PT182 } & \text { Alto Alentejo (I) } \\ \text { PT183 } & \text { Alentejo Central (I) } \\ \text { PT184 } & \text { Baixo Alentejo (I) } \\ \text { PT185 } & \text { Lezíria do Tejo (L) } \\ \text { PT200 } & \text { Açores (L) } \\ \text { PT300 } & \text { Madeira (L) } \\ & \end{array}$

Data source: Eurostat

http://ec.europa.eu/eurostat/ramon/nuts/pngmaps/pt3.png

http://epp.eurostat.ec.europa.eu/portal/page/portal/region_cities/regional_statistics/nuts_classific ation

Note: (L) indicates the Littoral (coastal) regions and (I) the Interior (inland) regions. 
Table 1. Per capita income of the Portuguese NUTS3 regions, 1996-2005 (constant prices, in thousands euros)

\begin{tabular}{|c|c|c|c|c|c|c|c|c|c|c|c|c|}
\hline & \multicolumn{12}{|c|}{ Years } \\
\hline Regions & \multicolumn{2}{|c|}{1996} & \multirow{2}{*}{$\begin{array}{c}1997 \\
8.451\end{array}$} & \multirow{2}{*}{$\begin{array}{c}1998 \\
8.826\end{array}$} & \multirow{2}{*}{$\begin{array}{c}1999 \\
9.249\end{array}$} & \multirow{2}{*}{$\begin{array}{c}2000 \\
9.360\end{array}$} & \multirow{2}{*}{$\begin{array}{c}\mathbf{2 0 0 1} \\
9.436\end{array}$} & \multirow{2}{*}{$\frac{2002}{9.464}$} & \multirow{2}{*}{$\begin{array}{c}\mathbf{2 0 0 3} \\
9.347\end{array}$} & \multirow{2}{*}{$\begin{array}{c}\mathbf{2 0 0 4} \\
9.3784\end{array}$} & \multicolumn{2}{|c|}{2005} \\
\hline Minho-Lima & 23rd & 8.189 & & & & & & & & & 27 th & 9.466 \\
\hline Cávado & 20th & 9.767 & 9.996 & 10.428 & 10.952 & 11.405 & 11.830 & 11.983 & 11.562 & 11.7656 & 18th & 11.748 \\
\hline Ave & 17 th & 10.524 & 10.873 & 11.346 & 11.939 & 12.068 & 12.083 & 12.134 & 11.838 & 11.5865 & 19th & 11.391 \\
\hline Grande Porto & $3 \mathrm{rd}$ & 14.439 & 14.993 & 15.644 & 16.048 & 16.108 & 16.079 & 15.500 & 14.984 & 15.1429 & 6th & 15.267 \\
\hline Tâmega & 29th & 6.700 & 7.191 & 7.631 & 7.971 & 8.272 & 8.456 & 8.562 & 8.298 & 8.2474 & 30th & 8.465 \\
\hline Entre Douro e Vouga & 10th & 11.154 & 11.671 & 12.553 & 13.198 & 12.838 & 13.257 & 13.548 & 12.398 & 12.3842 & 17 th & 12.466 \\
\hline Douro & 26th & 7.998 & 7.873 & 8.153 & 8.666 & 9.169 & 9.632 & 9.620 & 9.646 & 9.7070 & 26th & 10.204 \\
\hline Alto Trás-os-Montes & 25 th & 8.154 & 7.982 & 8.511 & 8.856 & 9.347 & 9.427 & 9.407 & 9.523 & 10.0114 & $23 \mathrm{rd}$ & 10.429 \\
\hline Baixo Vouga & 7 th & 12.220 & 12.813 & 13.462 & 14.265 & 14.101 & 14.070 & 14.190 & 13.889 & 14.0218 & 8th & 14.086 \\
\hline Baixo Mondego & 6th & 12.396 & 12.929 & 13.462 & 13.962 & 15.006 & 15.398 & 15.395 & 15.317 & 15.6411 & 5 th & 15.709 \\
\hline Pinhal Litoral & 5 th & 13.186 & 13.926 & 14.520 & 15.672 & 15.486 & 15.751 & 15.631 & 15.446 & 15.5096 & 7th & 15.248 \\
\hline Pinhal Interior Norte & 28th & 7.173 & 7.488 & 8.156 & 8.538 & 8.498 & 8.612 & 8.593 & 8.801 & 8.9546 & 29th & 9.009 \\
\hline Dão-Lafões & 24th & 8.158 & 8.488 & 9.040 & 9.715 & 10.302 & 10.490 & 10.332 & 10.404 & 10.6666 & $21 \mathrm{st}$ & 10.729 \\
\hline Pinhal Interior Sul & 22 th & 8.260 & 8.259 & 8.737 & 8.551 & 8.772 & 8.911 & 8.973 & 9.693 & 9.9689 & 24th & 10.428 \\
\hline Serra da Estrela & 30th & 6.314 & 6.745 & 7.222 & 7.761 & 7.948 & 8.076 & 8.474 & 8.904 & 9.1593 & 28th & 9.198 \\
\hline Beira Interior Norte & 27 th & 7.769 & 8.000 & 8.553 & 8.963 & 9.946 & 9.972 & 9.979 & 10.047 & 10.2402 & 22 th & 10.584 \\
\hline Beira Interior Sul & 9th & 11.193 & 11.328 & 12.021 & 12.132 & 12.766 & 12.645 & 12.628 & 12.583 & 12.7293 & $11 \mathrm{st}$ & 13.310 \\
\hline Cova da Beira & $21 \mathrm{st}$ & 8.761 & 8.815 & 9.273 & 9.791 & 9.841 & 9.888 & 9.795 & 9.306 & 9.6742 & 25 th & 10.225 \\
\hline Oeste & $12 \mathrm{nd}$ & 11.047 & 11.472 & 12.144 & 12.695 & 12.764 & 12.818 & 12.681 & 12.820 & 13.0150 & 15 th & 12.718 \\
\hline Médio Tejo & $11 \mathrm{st}$ & 11.089 & 11.604 & 12.163 & 12.813 & 13.294 & 13.410 & 13.193 & 13.184 & 13.2762 & 14 th & 12.846 \\
\hline Grande Lisboa & $1 \mathrm{st}$ & 19.637 & 20.921 & 22.234 & 23.399 & 24.663 & 24.847 & 25.058 & 24.822 & 25.2668 & $1 \mathrm{st}$ & 25.465 \\
\hline Península de Setúbal & 16th & 10.564 & 11.546 & 12.290 & 12.329 & 12.276 & 12.125 & 12.040 & 11.323 & 11.1834 & 20th & 11.045 \\
\hline Alentejo Litoral & 2 nd & 16.397 & 17.473 & 17.756 & 16.984 & 18.867 & 18.212 & 18.268 & 20.187 & 19.0898 & 2nd & 21.984 \\
\hline Alto Alentejo & 14th & 10.931 & 11.193 & 11.752 & 12.259 & 12.491 & 12.405 & 12.817 & 13.084 & 13.4567 & 12 th & 13.262 \\
\hline Alentejo Central & 18th & 10.438 & 11.088 & 11.697 & 12.044 & 13.448 & 13.436 & 13.207 & 13.170 & 13.2185 & 13th & 13.130 \\
\hline Baixo Alentejo & 15 th & 10.641 & 10.983 & 10.847 & 11.164 & 11.334 & 11.389 & 11.764 & 11.571 & 12.4143 & 16th & 12.711 \\
\hline Lezíria do Tejo & 8 th & 12.190 & 13.566 & 13.773 & 13.731 & 14.007 & 13.809 & 14.163 & 13.945 & 14.1952 & 10 th & 13.582 \\
\hline Algarve & 4 th & 13.323 & 14.021 & 14.647 & 15.338 & 15.916 & 16.227 & 16.277 & 16.177 & 16.0474 & 4th & 16.404 \\
\hline Açores & 19th & 10.155 & 10.496 & 11.151 & 11.988 & 12.409 & 13.095 & 13.458 & 13.536 & 13.5963 & 9th & 13.800 \\
\hline Madeira & 13th & 10.987 & 12.052 & 13.479 & 14.428 & 16.854 & 16.182 & 18.720 & 18.091 & 18.6977 & $3 \mathrm{rd}$ & 18.964 \\
\hline
\end{tabular}

Data source: National Institute of Statistics [40]

Notes: Monetary values for each NUTS3 region have been deflated by annual CPI of the

NUTS2 regions.

Regions have been ranked according to their relative position in the first and last years. 
Table 2. Per capita income of each region relative to the Portuguese weighted average, 1996-2005(percentage)

\begin{tabular}{|c|c|c|c|c|c|c|c|c|c|c|}
\hline \multirow[b]{2}{*}{ Regions } & \multicolumn{10}{|c|}{ Years } \\
\hline & 1996 & 1997 & 1998 & 1999 & 2000 & 2001 & 2002 & 2003 & 2004 & 2005 \\
\hline Minho-Lima & 65.04 & 63.74 & 63.12 & 63.40 & 61.99 & 62.05 & 61.98 & 62.20 & 61.73 & 61.89 \\
\hline Cávado & 77.57 & 75.39 & 74.57 & 75.08 & 75.53 & 77.80 & 78.48 & 76.94 & 77.44 & 76.80 \\
\hline Ave & 83.58 & 82.00 & 81.14 & 81.84 & 79.92 & 79.47 & 79.47 & 78.78 & 76.26 & 74.47 \\
\hline Grande Porto & 114.67 & 113.07 & 111.88 & 110.01 & 106.68 & 105.74 & 101.52 & 99.72 & 99.67 & 99.81 \\
\hline Tâmega & 53.21 & 54.23 & 54.58 & 54.64 & 54.78 & 55.61 & 56.07 & 55.22 & 54.28 & 55.34 \\
\hline Entre Douro e Vouga & 88.59 & 88.02 & 89.77 & 90.47 & 85.02 & 87.18 & 88.73 & 82.51 & 81.51 & 81.49 \\
\hline Douro & 63.52 & 59.38 & 58.30 & 59.40 & 60.72 & 63.34 & 63.01 & 64.19 & 63.89 & 66.71 \\
\hline Alto Trás-os-Montes & 64.76 & 60.20 & 60.86 & 60.71 & 61.90 & 62.00 & 61.61 & 63.37 & 65.89 & 68.18 \\
\hline Baixo Vouga & 97.05 & 96.64 & 96.27 & 97.78 & 93.38 & 92.53 & 92.94 & 92.43 & 92.29 & 92.09 \\
\hline Baixo Mondego & 98.45 & 97.51 & 96.27 & 95.71 & 99.38 & 101.26 & 100.83 & 101.93 & 102.94 & 102.70 \\
\hline Pinhal Litoral & 104.72 & 105.03 & 103.84 & 107.43 & 102.56 & 103.58 & 102.37 & 102.79 & 102.08 & 99.68 \\
\hline Pinhal Interior Norte & 56.97 & 56.47 & 58.33 & 58.53 & 56.28 & 56.63 & 56.28 & 58.56 & 58.94 & 58.90 \\
\hline Dão-Lafões & 64.79 & 64.01 & 64.65 & 66.60 & 68.23 & 68.99 & 67.67 & 69.23 & 70.20 & 70.14 \\
\hline Pinhal Interior Sul & 65.60 & 62.28 & 62.48 & 58.61 & 58.10 & 58.60 & 58.77 & 64.51 & 65.61 & 68.17 \\
\hline Serra da Estrela & 50.15 & 50.87 & 51.65 & 53.20 & 52.64 & 53.11 & 55.50 & 59.25 & 60.28 & 60.13 \\
\hline Beira Interior Norte & 61.70 & 60.33 & 61.17 & 61.44 & 65.87 & 65.58 & 65.36 & 66.86 & 67.40 & 69.19 \\
\hline Beira Interior Sul & 88.89 & 85.44 & 85.97 & 83.16 & 84.55 & 83.16 & 82.71 & 83.73 & 83.78 & 87.02 \\
\hline Cova da Beira & 69.58 & 66.48 & 66.32 & 67.12 & 65.17 & 65.03 & 64.15 & 61.93 & 63.67 & 66.85 \\
\hline Oeste & 87.74 & 86.52 & 86.85 & 87.03 & 84.53 & 84.30 & 83.05 & 85.31 & 85.66 & 83.15 \\
\hline Médio Tejo & 88.07 & 87.52 & 86.99 & 87.83 & 88.04 & 88.19 & 86.41 & 87.73 & 87.38 & 83.98 \\
\hline Grande Lisboa & 155.95 & 157.79 & 159.00 & 160.40 & 163.33 & 163.41 & 164.12 & 165.18 & 166.30 & 166.48 \\
\hline Península de Setúbal & 83.90 & 87.08 & 87.89 & 84.51 & 81.30 & 79.74 & 78.86 & 75.35 & 73.61 & 72.20 \\
\hline Alentejo Litoral & 130.23 & 131.78 & 126.98 & 116.42 & 124.95 & 119.77 & 119.65 & 134.34 & 125.64 & 143.72 \\
\hline Alto Alentejo & 86.81 & 84.41 & 84.04 & 84.03 & 82.72 & 81.58 & 83.94 & 87.07 & 88.57 & 86.70 \\
\hline Alentejo Central & 82.90 & 83.62 & 83.65 & 82.56 & 89.06 & 88.36 & 86.50 & 87.64 & 87.00 & 85.84 \\
\hline Baixo Alentejo & 84.51 & 82.83 & 77.57 & 76.53 & 75.06 & 74.90 & 77.05 & 77.00 & 81.71 & 83.10 \\
\hline Lezíria do Tejo & 96.82 & 102.31 & 98.50 & 94.13 & 92.76 & 90.81 & 92.76 & 92.80 & 93.43 & 88.79 \\
\hline Algarve & 105.81 & 105.74 & 104.75 & 105.14 & 105.40 & 106.72 & 106.61 & 107.65 & 105.62 & 107.24 \\
\hline Açores & 80.65 & 79.16 & 79.75 & 82.17 & 82.18 & 86.12 & 88.14 & 90.08 & 89.49 & 90.22 \\
\hline Madeira & 87.26 & 90.90 & 96.40 & 98.90 & 111.62 & 106.42 & 122.61 & 120.39 & 123.06 & 123.97 \\
\hline Littoral & 110.33 & 110.67 & 110.62 & 110.49 & 110.16 & 109.97 & 109.97 & 109.61 & 109.40 & 109.16 \\
\hline Interior & 67.88 & 66.59 & 66.51 & 66.70 & 67.50 & 67.88 & 67.67 & 68.60 & 69.09 & 69.68 \\
\hline
\end{tabular}

Data source: National Institute of Statistics [40]

Note: Monetary values for each NUTS3 region have been deflated by annual CPI of the NUTS2 regions. 
Table 3. $\sigma$-convergence in per capita income among the Portuguese NUTS3 regions, the Littoral and the Interior, 1996-2005.

\begin{tabular}{cccc|ccc}
\hline & \multicolumn{6}{c}{ Coefficient of variation } \\
\cline { 2 - 7 } Years & \multicolumn{3}{c}{ Total } & Littoral & Interior & \multicolumn{3}{c}{ Total } & Littoral & Interior \\
\cline { 2 - 7 } & To NU regions \\
\hline $\mathbf{1 9 9 6}$ & 0.271 & 0.227 & 0.193 & 0.280 & 0.231 & 0.193 \\
$\mathbf{1 9 9 7}$ & 0.283 & 0.233 & 0.193 & 0.293 & 0.239 & 0.193 \\
$\mathbf{1 9 9 8}$ & 0.279 & 0.230 & 0.184 & 0.289 & 0.238 & 0.184 \\
$\mathbf{1 9 9 9}$ & 0.274 & 0.225 & 0.178 & 0.283 & 0.235 & 0.178 \\
$\mathbf{2 0 0 0}$ & 0.284 & 0.244 & 0.186 & 0.290 & 0.255 & 0.186 \\
$\mathbf{2 0 0 1}$ & 0.277 & 0.237 & 0.177 & 0.285 & 0.251 & 0.177 \\
$\mathbf{2 0 0 2}$ & 0.282 & 0.242 & 0.172 & 0.283 & 0.252 & 0.172 \\
$\mathbf{2 0 0 3}$ & 0.285 & 0.258 & 0.167 & 0.289 & 0.272 & 0.167 \\
$\mathbf{2 0 0 4}$ & 0.279 & 0.259 & 0.166 & 0.280 & 0.270 & 0.166 \\
$\mathbf{2 0 0 5}$ & 0.288 & 0.280 & 0.153 & 0.290 & 0.294 & 0.153 \\
\hline
\end{tabular}

Data source: National Institute of Statistics [40]

Figure 2. Plot of $\sigma$-convergence in per capita income among the Portuguese NUTS3 regions, the Littoral and the Interior, 1996-2005.

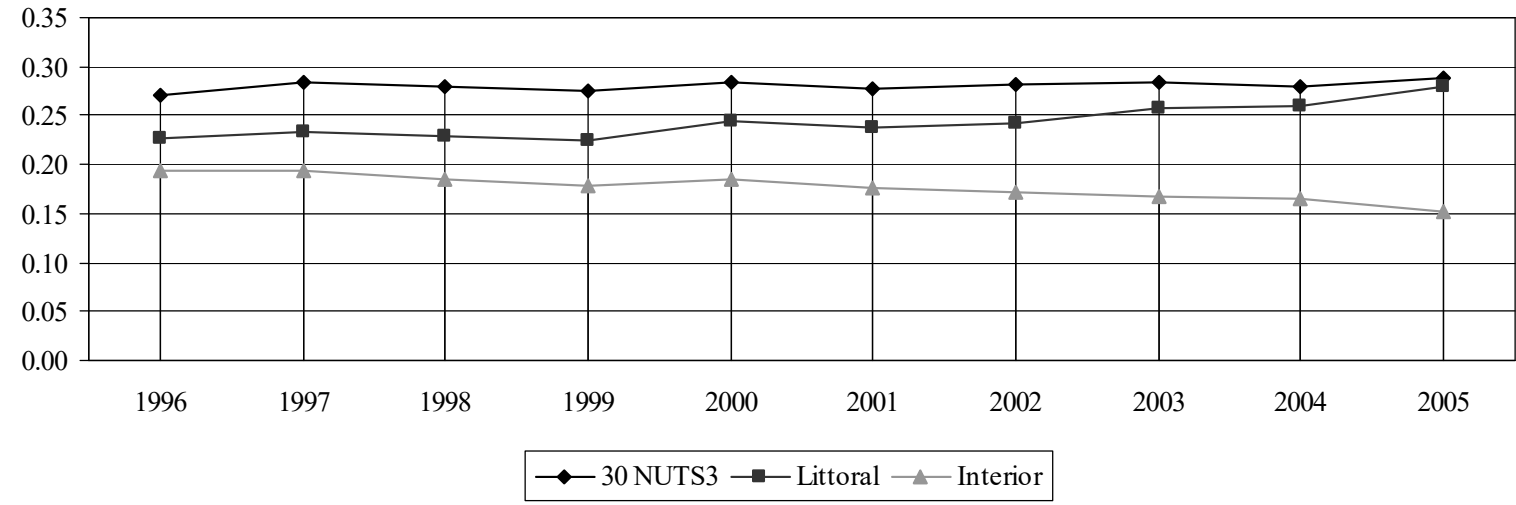

Data source: National Institute of Statistics [40] 
Table 4. Foreign trade indicators (\%), NUTS3 regions, 1996 and 2005.

\begin{tabular}{|c|c|c|c|c|c|c|c|c|}
\hline \multirow[b]{3}{*}{ Regions } & \multicolumn{8}{|c|}{ Years } \\
\hline & 1996 & 2005 & 1996 & 2005 & 1996 & 2005 & 1996 & 2005 \\
\hline & \multicolumn{2}{|c|}{ Open-Extra } & \multicolumn{2}{|c|}{ Open-Intra } & \multicolumn{2}{|c|}{$\frac{\text { Exports-Intra }}{\text { GDP }}$} & \multicolumn{2}{|c|}{$\frac{\text { (Total Exports) }}{\text { GDP }}$} \\
\hline Minho-Lima & 6.55 & 4.72 & 34.31 & 49.10 & 20.05 & 29.23 & 25.02 & 32.19 \\
\hline Cávado & 7.91 & 4.69 & 54.13 & 49.17 & 39.46 & 31.81 & 42.78 & 34.09 \\
\hline Ave & 19.25 & 16.64 & 71.56 & 68.86 & 50.89 & 45.89 & 59.85 & 54.73 \\
\hline Grande Porto & 12.73 & 13.29 & 39.91 & 44.14 & 16.31 & 15.04 & 21.39 & 22.79 \\
\hline Tâmega & 8.24 & 3.77 & 38.49 & 26.57 & 31.02 & 18.58 & 36.75 & 20.68 \\
\hline Entre Douro e Vouga & 20.59 & 19.64 & 70.61 & 84.14 & 47.32 & 53.82 & 61.95 & 68.00 \\
\hline Douro & 0.26 & 0.85 & 5.31 & 5.44 & 2.84 & 2.72 & 3.02 & 3.45 \\
\hline Alto Trás-os-Montes & 0.76 & 0.41 & 3.32 & 6.91 & 1.03 & 2.90 & 1.43 & 3.23 \\
\hline Baixo Vouga & 10.81 & 13.37 & 40.75 & 69.51 & 24.51 & 37.83 & 29.29 & 44.77 \\
\hline Baixo Mondego & 3.81 & 5.03 & 22.73 & 22.95 & 15.04 & 15.22 & 17.09 & 18.65 \\
\hline Pinhal Litoral & 5.58 & 5.80 & 28.00 & 29.43 & 13.00 & 13.64 & 16.96 & 17.06 \\
\hline Pinhal Interior Norte & 2.77 & 2.18 & 23.44 & 15.29 & 15.79 & 8.83 & 17.69 & 10.52 \\
\hline Dão-Lafões & 4.27 & 4.27 & 31.32 & 57.75 & 18.14 & 32.77 & 20.43 & 35.48 \\
\hline Pinhal Interior Sul & 0.64 & 0.42 & 13.28 & 7.19 & 9.06 & 5.74 & 9.39 & 5.99 \\
\hline Serra da Estrela & 0.87 & 1.04 & 8.16 & 5.10 & 3.43 & 2.24 & 3.88 & 2.67 \\
\hline Beira Interior Norte & 0.77 & 6.22 & 14.65 & 13.82 & 7.15 & 6.45 & 7.42 & 12.38 \\
\hline Beira Interior Sul & 3.31 & 1.11 & 11.43 & 9.43 & 5.38 & 5.63 & 8.42 & 6.69 \\
\hline Cova da Beira & 7.32 & 4.32 & 36.60 & 20.17 & 22.51 & 13.58 & 27.01 & 17.41 \\
\hline Oeste & 6.94 & 6.75 & 20.32 & 21.67 & 9.23 & 8.62 & 13.15 & 11.45 \\
\hline Médio Tejo & 12.64 & 11.64 & 22.54 & 30.54 & 9.41 & 15.45 & 12.88 & 17.61 \\
\hline Grande Lisboa & 17.18 & 19.95 & 42.46 & 46.27 & 8.27 & 7.75 & 11.96 & 11.35 \\
\hline Península de Setúbal & 10.71 & 9.25 & 77.93 & 52.39 & 53.14 & 32.74 & 58.46 & 35.91 \\
\hline Alentejo Litoral & 10.35 & 9.25 & 14.86 & 52.39 & 8.68 & 24.60 & 12.18 & 27.44 \\
\hline Alto Alentejo & 2.43 & 3.88 & 17.52 & 18.66 & 9.41 & 9.19 & 10.53 & 10.07 \\
\hline Alentejo Central & 1.81 & 5.28 & 10.41 & 16.98 & 5.54 & 10.27 & 6.98 & 14.96 \\
\hline Baixo Alentejo & 0.50 & 1.62 & 2.58 & 13.62 & 0.50 & 13.52 & 0.80 & 15.06 \\
\hline Lezíria do Tejo & 6.13 & 7.32 & 47.90 & 76.83 & 19.16 & 28.29 & 23.11 & 33.47 \\
\hline Algarve & 0.69 & 0.51 & 3.38 & 3.80 & 1.48 & 1.18 & 1.84 & 1.40 \\
\hline 28 NUTS3 Average & 6.64 & 6.54 & 28.85 & 32.79 & 16.70 & 17.63 & 20.06 & 21.05 \\
\hline Littoral & 9.95 & 9.73 & 40.63 & 47.90 & 23.32 & 24.69 & 28.22 & 29.52 \\
\hline Interior & 3.33 & 3.36 & 17.07 & 17.68 & 10.09 & 10.56 & 11.90 & 12.59 \\
\hline
\end{tabular}

Data source: National Institute of Statistics [41]

Note: Monetary values for each NUTS3 region have been deflated by annual CPI of the NUTS2 regions. 
Table 5. Scholar success rate in high school (\%), NUTS3 regions, 1996-2005.

\begin{tabular}{|c|c|c|c|c|c|c|c|c|c|c|}
\hline \multirow{2}{*}{ Regions } & \multicolumn{10}{|c|}{ Years } \\
\hline & 1996 & 1997 & 1998 & 1999 & 2000 & 2001 & 2002 & 2003 & 2004 & 2005 \\
\hline Minho-Lima & 72.49 & 68.51 & 67.09 & 66.13 & 63.99 & 62.56 & 64.97 & 69.95 & 72.27 & 73.41 \\
\hline Cávado & 68.36 & 62.53 & 65.74 & 66.58 & 66.08 & 61.43 & 66.43 & 68.55 & 66.73 & 68.08 \\
\hline Ave & 65.98 & 67.38 & 65.78 & 66.20 & 66.95 & 61.78 & 65.25 & 69.35 & 69.35 & 71.72 \\
\hline Grande Porto & 68.72 & 66.30 & 68.61 & 66.54 & 63.94 & 58.14 & 62.69 & 67.01 & 69.00 & 71.10 \\
\hline Tâmega & 66.56 & 66.87 & 64.93 & 64.43 & 63.51 & 64.12 & 66.47 & 70.64 & 70.03 & 69.34 \\
\hline Entre Douro e Vouga & 62.49 & 60.06 & 68.03 & 69.49 & 70.76 & 68.46 & 69.86 & 71.88 & 71.36 & 69.36 \\
\hline Douro & 65.01 & 62.19 & 62.79 & 63.29 & 63.27 & 58.39 & 59.69 & 67.76 & 65.94 & 68.96 \\
\hline Alto Trás-os-Montes & 66.06 & 63.69 & 62.26 & 62.00 & 61.31 & 55.48 & 58.82 & 65.42 & 62.93 & 64.26 \\
\hline Baixo Vouga & 61.07 & 61.78 & 63.58 & 63.66 & 64.11 & 60.76 & 60.29 & 66.75 & 64.52 & 67.83 \\
\hline Baixo Mondego & 66.34 & 65.94 & 66.99 & 66.20 & 64.97 & 65.72 & 63.60 & 67.96 & 69.32 & 70.99 \\
\hline Pinhal Litoral & 64.76 & 64.03 & 65.68 & 64.62 & 63.36 & 63.41 & 62.30 & 65.65 & 66.54 & 68.45 \\
\hline Pinhal Interior Norte & 62.55 & 64.24 & 61.84 & 61.60 & 61.59 & 58.59 & 61.80 & 63.38 & 62.50 & 63.45 \\
\hline Dão-Lafões & 64.62 & 60.84 & 64.44 & 64.17 & 63.49 & 65.67 & 65.02 & 66.94 & 67.59 & 68.29 \\
\hline Pinhal Interior Sul & 70.02 & 62.52 & 60.20 & 63.06 & 64.03 & 64.93 & 61.95 & 70.29 & 72.56 & 68.55 \\
\hline Serra da Estrela & 66.37 & 62.87 & 63.63 & 64.49 & 65.12 & 61.40 & 64.69 & 67.46 & 65.78 & 65.43 \\
\hline Beira Interior Norte & 65.93 & 62.54 & 63.39 & 63.89 & 62.40 & 56.09 & 59.01 & 66.26 & 66.46 & 66.39 \\
\hline Beira Interior Sul & 66.23 & 63.22 & 57.84 & 61.25 & 61.18 & 58.42 & 62.41 & 66.52 & 66.17 & 69.40 \\
\hline Cova da Beira & 64.13 & 62.58 & 66.03 & 62.84 & 58.99 & 63.21 & 60.03 & 65.06 & 65.34 & 68.37 \\
\hline Oeste & 59.15 & 62.08 & 63.37 & 65.24 & 66.55 & 62.69 & 63.45 & 65.48 & 65.07 & 64.18 \\
\hline Médio Tejo & 72.45 & 65.32 & 66.46 & 65.48 & 65.04 & 65.32 & 65.15 & 68.76 & 68.00 & 66.07 \\
\hline Grande Lisboa & 68.80 & 64.48 & 64.56 & 62.75 & 60.78 & 59.07 & 62.04 & 64.99 & 64.63 & 67.44 \\
\hline Península de Setúbal & 65.86 & 62.72 & 61.65 & 61.49 & 61.30 & 57.63 & 60.30 & 64.25 & 62.79 & 66.33 \\
\hline Alentejo Litoral & 63.42 & 58.15 & 56.86 & 58.27 & 59.36 & 56.34 & 57.56 & 59.37 & 70.75 & 70.12 \\
\hline Alto Alentejo & 72.57 & 61.52 & 67.96 & 66.63 & 65.90 & 62.39 & 63.82 & 64.53 & 61.94 & 66.69 \\
\hline Alentejo Central & 66.63 & 67.84 & 61.43 & 62.54 & 62.73 & 60.21 & 62.43 & 67.08 & 69.05 & 68.16 \\
\hline Baixo Alentejo & 65.52 & 56.03 & 59.54 & 60.41 & 62.04 & 59.70 & 60.33 & 61.64 & 62.83 & 61.56 \\
\hline Lezíria do Tejo & 67.22 & 68.18 & 63.06 & 65.63 & 67.05 & 60.50 & 59.54 & 64.29 & 65.12 & 66.67 \\
\hline Algarve & 63.75 & 60.16 & 58.76 & 57.74 & 56.19 & 57.80 & 60.59 & 63.31 & 61.71 & 64.75 \\
\hline Açores & 64.16 & 61.80 & 58.82 & 60.65 & 59.94 & 55.77 & 53.91 & 60.11 & 61.02 & 66.12 \\
\hline Madeira & 76.36 & 74.52 & 65.50 & 67.82 & 73.56 & 70.11 & 70.05 & 68.12 & 65.01 & 62.32 \\
\hline 30 NUTS3 Average & 66.45 & 63.70 & 63.56 & 63.84 & 63.65 & 61.20 & 62.48 & 66.29 & 66.41 & 67.46 \\
\hline Littoral & 66.18 & 64.29 & 64.01 & 64.31 & 64.31 & 61.38 & 62.68 & 66.06 & 66.57 & 68.05 \\
\hline Interior & 66.76 & 63.02 & 63.05 & 63.29 & 62.90 & 61.00 & 62.26 & 66.55 & 66.22 & 66.78 \\
\hline
\end{tabular}

Data source: Office of Statistics and Education Planning and National Institute of Statistics [42] 
Table 6. Employment share by sector (\%), NUTS3 regions, 1996 and 2005.

\begin{tabular}{|c|c|c|c|c|c|c|c|c|c|}
\hline \multirow{2}{*}{ Regions } & \multicolumn{3}{|c|}{ Prim } & \multicolumn{3}{|c|}{ Sec } & \multicolumn{3}{|c|}{ Ter } \\
\hline & 1996 & 2005 & Variation & 1996 & 2005 & Variation & 1996 & 2005 & Variation \\
\hline Minho-Lima & 30.09 & 26.57 & -3.53 & 31.55 & 30.61 & -0.94 & 38.36 & 42.83 & 4.47 \\
\hline Cávado & 13.70 & 10.00 & -3.71 & 47.01 & 45.11 & -1.90 & 39.29 & 44.90 & 5.61 \\
\hline Ave & 7.86 & 7.09 & -0.77 & 64.36 & 59.03 & -5.33 & 27.78 & 33.88 & 6.10 \\
\hline Grande Porto & 2.36 & 2.25 & -0.11 & 36.82 & 28.97 & -7.85 & 60.82 & 68.78 & 7.96 \\
\hline Tâmega & 19.25 & 15.54 & -3.71 & 53.61 & 51.98 & -1.63 & 27.14 & 32.48 & 5.34 \\
\hline Entre Douro e Vouga & 7.66 & 8.04 & 0.38 & 65.11 & 57.44 & -7.67 & 27.23 & 34.51 & 7.29 \\
\hline Douro & 49.92 & 43.22 & -6.69 & 14.03 & 13.79 & -0.24 & 36.05 & 42.98 & 6.94 \\
\hline Alto Trás-os-Montes & 56.54 & 47.41 & -9.13 & 9.33 & 12.65 & 3.32 & 34.14 & 39.94 & 5.81 \\
\hline Baixo Vouga & 19.36 & 15.50 & -3.85 & 42.39 & 38.31 & -4.08 & 38.25 & 46.18 & 7.93 \\
\hline Baixo Mondego & 22.72 & 16.48 & -6.24 & 22.99 & 19.62 & -3.37 & 54.29 & 63.90 & 9.61 \\
\hline Pinhal Litoral & 19.06 & 11.45 & -7.61 & 41.21 & 41.49 & 0.29 & 39.73 & 47.06 & 7.32 \\
\hline Pinhal Interior Norte & 34.27 & 29.15 & -5.12 & 33.01 & 33.00 & -0.01 & 32.72 & 37.86 & 5.14 \\
\hline Dão-Lafões & 40.09 & 35.30 & -4.80 & 25.46 & 24.92 & -0.54 & 34.44 & 39.78 & 5.34 \\
\hline Pinhal Interior Sul & 54.25 & 50.20 & -4.05 & 22.24 & 19.64 & -2.60 & 23.51 & 30.16 & 6.65 \\
\hline Serra da Estrela & 41.56 & 26.80 & -14.76 & 23.77 & 30.87 & 7.10 & 34.68 & 42.33 & 7.65 \\
\hline Beira Interior Norte & 48.88 & 43.56 & -5.32 & 16.64 & 16.42 & -0.22 & 34.48 & 40.02 & 5.54 \\
\hline Beira Interior Sul & 36.62 & 38.52 & 1.90 & 22.80 & 17.78 & -5.02 & 40.58 & 43.71 & 3.12 \\
\hline Cova da Beira & 30.79 & 32.02 & 1.24 & 33.53 & 26.28 & -7.25 & 35.68 & 41.69 & 6.01 \\
\hline Oeste & 29.80 & 19.63 & -10.17 & 29.53 & 29.28 & -0.25 & 40.67 & 51.09 & 10.42 \\
\hline Médio Tejo & 23.84 & 16.80 & -7.04 & 29.68 & 29.52 & -0.16 & 46.48 & 53.68 & 7.20 \\
\hline Grande Lisboa & 0.67 & 0.71 & 0.04 & 22.89 & 18.60 & -4.29 & 76.44 & 80.69 & 4.25 \\
\hline Península de Setúbal & 3.11 & 3.22 & 0.11 & 34.52 & 28.32 & -6.20 & 62.37 & 68.46 & 6.09 \\
\hline Alentejo Litoral & 14.57 & 16.05 & 1.48 & 26.87 & 21.77 & -5.10 & 58.57 & 62.18 & 3.61 \\
\hline Alto Alentejo & 16.03 & 16.95 & 0.91 & 26.73 & 21.89 & -4.84 & 57.24 & 61.17 & 3.93 \\
\hline Alentejo Central & 9.66 & 12.20 & 2.53 & 28.90 & 25.09 & -3.81 & 61.43 & 62.71 & 1.28 \\
\hline Baixo Alentejo & 17.47 & 20.97 & 3.50 & 17.92 & 16.37 & -1.55 & 64.60 & 62.66 & -1.94 \\
\hline Lezíria do Tejo & 14.24 & 10.36 & -3.87 & 34.96 & 31.33 & -3.63 & 50.80 & 58.30 & 7.50 \\
\hline Algarve & 10.89 & 6.87 & -4.02 & 16.51 & 21.76 & 5.25 & 72.60 & 71.37 & -1.23 \\
\hline Açores & 16.51 & 13.78 & -2.73 & 21.93 & 22.85 & 0.91 & 61.56 & 63.38 & 1.81 \\
\hline Madeira & 17.10 & 8.38 & -8.72 & 25.77 & 25.57 & -0.20 & 57.13 & 66.05 & 8.92 \\
\hline 30 NUTS3 Average & 24.12 & 20.82 & -3.30 & 31.23 & 28.99 & -2.23 & 44.66 & 50.19 & 5.53 \\
\hline Littoral & 14.01 & 11.02 & -2.99 & 36.91 & 33.69 & -3.22 & 49.09 & 55.30 & 6.21 \\
\hline Interior & 34.23 & 30.62 & -3.61 & 25.55 & 24.30 & -1.25 & 40.23 & 45.08 & 4.86 \\
\hline
\end{tabular}

Data Source: National Institute of Statistics [40]

Note:

The primary sector (PRIM) includes agriculture, hunting, forestry, fishing and aquaculture. The secondary sector $(S E C)$ embraces industry, including energy and construction. The tertiary sector $(T E R C)$ refers to services. 
Table 7. GMM Regressions of the conditional convergence equation for the 28 NUTS3 regions of the Portuguese Continent. Balanced panel data, 1996-2005.

Variables

$\operatorname{lnGDPpc} c_{\mathrm{i},-1}$

$(-3.36)$

$\ln \left(\mathrm{n}_{\mathrm{i}, \mathrm{t}}+\mathrm{g}+\delta\right)$

(1)

0.1236
(2)

(3)

$(1.01)$

0.1334

$(1.14)$
(4)

(5)

$-0.1451 * * *$

$(-2.93)$

\begin{tabular}{|c|c|c|c|c|c|c|c|}
\hline $\mathrm{Sec}_{\mathrm{i}, \mathrm{t}}$ & & & $\begin{array}{c}0.0099 * * * \\
(3.48) \\
\end{array}$ & $\begin{array}{c}0.0110^{* * *} \\
(4.07)\end{array}$ & $\begin{array}{c}0.0110^{* * *} \\
(4.13) \\
\end{array}$ & $\begin{array}{c}0.0115^{* * *} \\
(5.03) \\
\end{array}$ & $\begin{array}{c}0.0055^{* *} \\
(2.27)\end{array}$ \\
\hline $\ln (\text { School })_{\mathrm{i}, \mathrm{t}-1}$ & $\begin{array}{c}0.1982 * * \\
(2.70) \\
\end{array}$ & $\begin{array}{c}0.1586^{* *} \\
(2.48) \\
\end{array}$ & $\begin{array}{c}0.1478 * \\
(1.94)\end{array}$ & $\begin{array}{c}0.1872^{* *} \\
(2.53) \\
\end{array}$ & $\begin{array}{c}0.1467 * \\
(2.04)\end{array}$ & $\begin{array}{c}0.1446^{* *} \\
(2.32) \\
\end{array}$ & \\
\hline $\ln (\text { Open-Extra })_{\mathrm{i}, \mathrm{t}-1} *$ Littoral $_{\mathrm{i}}$ & $\begin{array}{c}0.0350 * \\
(2.03)\end{array}$ & & & $\begin{array}{c}0.0275^{*} \\
(1.89)\end{array}$ & & & \\
\hline $\ln (\text { Exports-Intra/GDP })_{\mathrm{i}, \mathrm{t}-1} *$ Littoral $_{\mathrm{i}}$ & & $\begin{array}{c}0.0603 * * \\
(2.59) \\
\end{array}$ & & & $\begin{array}{c}0.0547 * * \\
(2.52) \\
\end{array}$ & & \\
\hline TB-Intra $\mathrm{i}_{\mathrm{i}, \mathrm{-}}$ & & & $\begin{array}{c}0.0065^{*} \\
(1.88) \\
\end{array}$ & & & & \\
\hline \multicolumn{8}{|l|}{$\ln (\text { Open-Intra })_{i, t} *$ Littoral $_{i}$} \\
\hline $\ln (\text { Total-Exports/GDP })_{\mathrm{i}, \mathrm{t}-1} *$ Littoral $_{\mathrm{i}}$ & & & & & & $\begin{array}{c}0.0399 * \\
(1.72)\end{array}$ & \\
\hline $\mathrm{g}(\text { Exports-Extra/GDP })_{\mathrm{i}, \mathrm{t}}$ & & & & & & & $\begin{array}{c}-0.0217^{*} \\
(-1.74)\end{array}$ \\
\hline $\ln (\text { School })_{i, t}{ }^{*} g(\text { Exports-Extra/GDP })_{i, t}$ & & & & & & & $\begin{array}{c}0.0053^{*} \\
(1.75)\end{array}$ \\
\hline $\ln (\text { School })_{i, t}$ & & & & & & & $\begin{array}{r}-0.0153 \\
(-0.12) \\
\end{array}$ \\
\hline Constant & & & & & & & $\begin{array}{c}0.4526 \\
(0.78) \\
\end{array}$ \\
\hline Observations & 224 & 224 & 224 & 224 & 224 & 224 & 252 \\
\hline No. regions & 28 & 28 & 28 & 28 & 28 & 28 & 28 \\
\hline No. instruments & 22 & 22 & 24 & 22 & 22 & 22 & 26 \\
\hline Hansen J-test & 25.32 & 25.47 & 22.32 & 16.39 & 15.54 & 15.49 & 22.58 \\
\hline p-value & 0.116 & 0.112 & 0.323 & 0.565 & 0.625 & 0.628 & 0.310 \\
\hline AR2 test & 0.067 & 0.199 & 0.657 & -0.199 & -0.085 & -0.115 & -0.052 \\
\hline p-value & 0.946 & 0.842 & 0.511 & 0.842 & 0.932 & 0.908 & 0.959 \\
\hline
\end{tabular}

\section{Notes:}

Columns (1), (2), (4) and (5) - 1-step difference $G M M$, with robust standard errors and the options "collapse" and "lag (1 to 7)".

Column (3) - 1-step difference GMM, with robust standard errors and the options "collapse" and "lag (1 to 6)".

Column (6) - 2-step difference GMM, with robust standard errors and the options "collapse" and "lag (1 to 7)".

Column (7) - 2-step system GMM, with robust standard errors and the options "collapse" and "lag (1 to 5)".

The interaction term of each regression is exogenous (Difference-in-Hansen test).

Values in parenthesis are t-ratio.

* Coefficient significant at the 10\% level;** Coefficient significant at the 5\% level; *** Coefficient significant at the $1 \%$ level.

Hansen J-test - overidentification test of restrictions in GMM estimation.

AR2 test - Arellano-Bond's test to analyse the existence of $2^{\text {nd }}$ order autocorrelation in first differences. 


\section{References}

[1] R. Barro, X. Sala-i-Martin, Economic growth in a cross-section of countries, The Quarterly Journal of Economics 1062 (1991) 407-443.

[2] A. Cappelen, J. Fagerberg, B. Verspagen, Lack of regional convergence, Paper presented at the EAEPE 1999 conference, $4^{\text {th }}-7^{\text {th }}$ November, Prague, Czech Republic (1999).

[3] M. Battisti, G. Di Vaio, A spatially filtered mixture of $\beta$-convergence regressions for EU regions, 1980-2002, Empirical Economics 34 (2008) 105-121.

[4] V. Meliciani, F. Peracchi, Convergence in per capita GPD across European regions: a reappraisal, Empirical Economics 31 (2006) 549-568.

[5] B. Herz, L. Vogel, Regional convergence in Central and Eastern Europe: evidence from a decade of transition, Diskussionpapier 13-03 Universität Bayreuth September (2003).

[6] A. De La Fuente, On the sources of convergence: a close look at the Spanish regions, European Economic Review 46 (2002) 569-599.

[7] D. Vittorio, Regional convergence and public spending in Italy. Is there a correlation?, MPRA Paper 14334 (2009).

[8] L. Michelis, A. Papadopoulos, G. Papanikos, Regional convergence in Greece in the 1980s: an econometric investigation, Applied Economics 36 (2004) 881-888.

[9] N. Crespo, A. Fontoura, Economic centrality, per capita income and human capital some results at regional and local level in 275 counties of Portugal, Regional and Sectoral Economic Studies 61 (2006) 75-84.

[10] N. Crespo, A. Fontoura, Determinant factors of structural similarity at the regional level: evidence from Portugal, Working Paper 28/2009 ISEG (2009).

[11] M. Antunes, E. Soukiazis, Two speed regional convergence in Portugal and the importance of structural funds on growth., Ekonomia 92 Winter (2006) 222-241. 
[12] E. Soukiazis, S. Proença, Tourism as an alternative source of regional growth in Portugal: a panel data analysis at NUTS II and III levels, Portuguese Economic Journal 7 (2008) 43-61.

[13] P. Ramos, Does the trade balance really matter for regions?, The Annals of Regional Science 41 (2007) 229-243.

[14] T. Bayoumi, A. Rose, Domestic savings and intra-national capital flows, European Economic Review 376 (1993) 1197-1202.

[15] J. Helliwell, R. McKitrick, Comparing capital mobility across provincial and national borders, Canadian Journal of Economics 325 (1999) 1164-1173.

[16] J. Decressin, P. Disyatat, Capital markets and external current account: what to expect from the Euro, IMF Working Paper WP/00/154 (2000).

[17] A. Thirlwall, Regional problems are "balance-of-payments" problems, Regional Studies 14 (1980) 419-425.

[18] R. Solow, A contribution to the theory of economic growth, The Quarterly Journal of Economics 701 (1956) 65-94.

[19] P. Romer, Increasing returns and long-run growth, Journal of Political Economy 94 5 (1986) 1002-1037.

[20] W. Baumol, Productivity growth, convergence and welfare: what the long-run data show, The American Economic Review 765 (1986) 1072-1085.

[21] R. Barro, X. Sala-i-Martin, Convergence, Journal of Political Economy 1002 (1992) 223-251.

[22] G. Mankiw, D. Romer, D. Weil, A contribution to the empirics of economic growth, The Quarterly Journal of Economics 1072 (1992) 407-437.

[23] N. Islam, Growth empirics: a panel data approach, The Quarterly Journal of Economics 1104 (1995) 1127-1171.

[24] O. Galor, Convergence? Inferences from theoretical models, The Economic Journal 106 (1996) 1056-1069. 
[25] J. Temple, The new growth evidence, Journal of Economic Literature 371 (1999) 112-156.

[26] M. Antunes, E. Soukiazis, Foreign trade, human capital and economic growth: an empirical approach for the EU countries., CEUNEUROP Discussion Paper 51 - FEUC (2009).

[27] G. Grossman, E. Helpman, Innovation and growth in the global economy, MIT Press, Cambridge and Massachussets, 1991.

[28] H. Yanikkaya, Trade openness and economic growth: a cross-country empirical investigation, Journal of Development Economics 72 (2003) 57-89.

[29] A. Di Liberto, Convergence and divergence in neoclassical growth models with human capital, CRENoS Working Paper 8 - Centre for North South Economic Research University of Cagliari and Sassari (2005).

[30] D. Coe, E. Helpman, A. Hoffmaister, North R\&D spillovers, The Economic Journal 107 (1997) 134-149.

[31] G. Tondl, Convergence after divergence? Regional growth in Europe., Springer, Wien, 2001.

[32] F. Caselli, G. Esquivel, F. Lefort, Reopening the convergence debate: a new look at cross-country growth empirics, Journal of Economic Growth 1 September (1996).

[33] S. Bond, A. Hoeffler, J. Temple, GMM estimation of empirical growth models, CEPR Discussion Papers no 3048 (2001).

[34] M. Arellano, S. Bond, Some tests of specification for panel data: Monte Carlo evidence and an application to employment equations, Review of Economic Studies 58 (1991) 277-297.

[35] C. Baum, An introduction to modern econometrics using Stata, Stata Press, College Station, 2006.

[36] M. Arellano, O. Bover, Another look at the instrumental variable estimation of error-component models, Journal of Econometrics 68 (1995) 29-51. 
[37] R. Blundell, S. Bond, Initial conditions and moment restrictions in dynamic panel data models, Journal of Econometrics 87 (1998) 115-43.

[38] D. Roodman, How to do xtabond2: an introduction to "difference" and "system" in Stata, Center for Global Development Working Paper 103 December (2006).

[39] R. Barro, X. Sala-i-Martin, Economic growth, $2^{\text {nd }}$ ed., MIT Press, Cambridge, 2004.

[40] National Institute of Statistics, Regional economic evolution (2008).

[41] National Institute of Statistics, The country in numbers (CD-ROM) (2007).

[42] Office of Statistics and Education Planning and National Institute of Statistics, 50 years of educational statistics (non-superior schooling), Lisbon, Portugal (2009). 